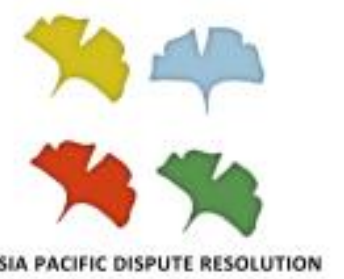

\title{
An Analysis of the Social and Legal Problems in Transitional China
}

\author{
Shuliang Wang
}

\author{
Shanghai Academy of Social Sciences
}

\author{
APDR Working Paper Series \\ Volume 2 Number 1
}

ISSN 2371-6304

(c) (i) (9)

by Shuliang Wang, 2017.

This article is made available as part of the Asia Pacific Dis pute Resolution Working Paper Series and is licensed under a Creative Commons Attribution-NonCommercial-NoDerivatives 4.0 International License 


\title{
AN ANALYSIS OF THE SOCIAL AND LEGAL PROBLEMS IN TRANSITIONAL CHINA
}

\author{
Shuliang Wang* \\ Shanghai Academy of Social Sciences (SASS)
}

Under the leadership of Xi Jinping, the General Secretary of the Communist Party of China (CPC), China has entered into a new stage of development. It is historical for its great importance to the development of China and the pursuit of the 'Chinese dream' - the peaceful rise of the Chinese nation. With the policy of further 'reform and opening-up', it is the aim and motivation of the Chinese government to make all Chinese people benefit from the achievement of this policy. However, the deepening reform and the continuous changes of society have also bred various conflicts of interests, which have manifested in a wide range of forms. The government should strive to solve the conflicts, as if these conflicts of interests are not addressed appropriately, could easily cause social unrest and thus challenge the rule of law in China. China is building up a country with a socialist rule of law, which has never been established before in any other country and thus, has no existing model to learn from. Therefore, it is important to investigate the social context creating the social conflicts in order to obtain better strategies to establish the rule of law in China. China is currently undergoing a tremendous transition, with numerous and endless social conflicts taking place. The concept of Transitional Society is a useful context within which to investigate and address the social problems in China, and thus is important for the establishment of the rule of law in China.

1. China is in a Transition from Planned Economy to Market Economy

When the People's Republic of China (PRC) was first established in 1949, China was isolated by the western countries headed by the United States because of the ideological disparity, and thereby, China adopted a foreign policy of being 'one-sided' to the Soviet Union. China copied

\footnotetext{
* This article is funded by the Asia Pacific Dispute Resolution Research (APDR) Project: Understanding Integrated Compliance with International Trade and Human Rights Standards in Comparative Perspective sponsored by the Social Sciences and Research Council of Canada (SSHRC).
} 
and transferred the Soviet model to establish its economic structures and policies, established the socialist state ownership and collective ownership on means of production, and founded a thorough and national planned economic system in a very short period of time. Although China made great economic achievements under the planned economy and immediately changed its previous status as a very 'poor and blank' country, ${ }^{1}$ the Soviet Union planned economic model in China gradually revealed its inherent disadvantages, including the excessive concentration of power, the rigid mechanism of operation, the low efficiency of labor, the waste of production, the lack of vitality of the economy, and the low motivation of laborers. These problems seriously hindered the progress of China's economy and society. The standard of living in China was very low, and people in some rural areas were in absolute poverty and lacked food and clothing even after the PRC had been established for thirty years. The planned economic model turned out to be unsustainable, which partially caused the social collapse in the Soviet Union and other eastern European socialist countries.

By pointing out that 'poverty is not part of socialism,' and 'slow development is not equivalent to socialism as well', ${ }^{2}$ Deng Xiaoping, the great leader of China criticized the previous economic model and proposed a new development model, which not only accelerated China's economic growth but also enhanced the confidence of the Chinese to establish the socialist country. To transform the planned economy to market economy is the only approach for China to address the existing economic difficulties.

The market economy emphasizes objective economic laws and regulations, and relies on the 'invisible hand' of the market to adjust the economy in order to achieve the rational distribution of social resources and productive powers. The market economy has its drawbacks, so it is important to establish the new socialist market economy by minimizing or eliminating the unfavorable factors of the market economy, and withdrawing government's functions from overintervention in the economy.

However, it was a great challenge to transform a planned economy to a socialist market economy in theory and practice, especially in China, as at that time, most people regarded the planned economy as 'equivalent to' socialism and market economy as ‘equivalent to' capitalism.

\footnotetext{
${ }^{1}$ More exactly, the planned economy played a noticeable role in recovering and establishing the economy in the preliminary PRC.

2 Selected Work of Deng Xiaoping, vol.3 (Renming Press, 1993) p. 255.
} 
To change this mindset, Deng Xiaoping gave his famous southern tour speech in $1992^{3}$ pointing out that the 'reform and opening-up' would be slow because people worried that absorbing more capitalist elements in the reform would make China a capitalist country. However, he emphasized that the criteria for judging the reform should mainly focus on whether the reform was beneficial for the development of the productive power in socialist countries, for enhancing the national strength of socialist countries, and for improving people's lives. "More planning or more market element is not the standard of evaluation. A planned economy is not equivalent to socialism, because there is planning under capitalism too; a market economy is not capitalism, because socialism also has a market. Planning and market are both economic means." ${ }^{4}$ Deng Xiaoping's speech fundamentally removed the ideological barriers regarding the planned economy and the market economy as belonging to specific social economic systems.

Finally, by implementing the 'reform and opening-up' policy for thirty years, China's economic system has successfully shifted from the original planned economy to market economy. The suppressed productive power and enthusiasm have been fully mobilized, people's living standard has continuously improved, and food and clothing problems have been generally addressed. China is moving from 'moderate prosperous' country to 'high prosperous' country, and the country's comprehensive national strength and the wealth of all members of society have been greatly enhanced.

However, it should be noted that, along with changes in the economic model by regulating the country's economic activities more through market than administrative means, many economic and social structures and practices under the planned economy were no longer consistent with the requirements of the market economy and needed reform. For instance, in the 'planned economy' era, the state strictly planned and arranged the activities of production and sales in the state-owned and collectively owned economic bodies, and the state also arranged the employment, housing, healthcare and other aspects of the workers' welfare. These have been excessively claimed as the advantages of socialism and thus covered up the low efficiency and poor social welfare associated with socialism. Moreover, in the long run, such welfare policies were not sustainable because of the poor economic condition of the state. Since the 'reform and

\footnotetext{
${ }^{3}$ Speeches that Deng Xiaoping gave when he toured Wuchang, Shenzhen, Zhuhai, Shanghai from Jan. 18, 1992 to Feb. 21, 1992.

${ }^{4}$ Jinsheng Ye, "Deng Xiaoping Theory and Practice of Socialist Market Economy" (2009), online:

<http://theory.people.com.cn/GB/10335079.html>.
} 
opening-up', the permanent employment of workers, so called 'iron rice bowl' has been replaced by a new type of labor relations; the welfare housing of urban residents has been reformed into commercialized housing; and the healthcare system has shifted from the public funded system to a system funded mainly by public sources with some private funding as supplement. All these reforms have profoundly changed the lives of the Chinese people and have greatly shaped the Chinese society. They resulted in a series of social and legal issues, such as: how to protect the legal rights and interests of workers while ensuring the autonomy of employers in the open labor market; how to protect the housing rights of the economic worse-off and the disadvantaged social groups in the commercialized housing market; and how to protect the health and medical rights of citizens after the public funded health care system changed?

These social and legal issues, on the one hand, are partially derived from the striking shift of people's ideas and lifestyles brought by the reform, but on the other hand, are closely related to some inappropriate and irrational strategies taken by the reform. It is not possible to go back, and the deepening of the reform must be carried on. Thus, the CPC as the ruling party in China must make efforts to address these social and legal issues such as: how to legally and practically improve the labor relations in the market economy: how to protect the legal rights and interests of laborers: and how to protect the health and medical right of citizens equally.

Meanwhile, it should also be considered that the shift from a planned economy to a market economy is not only a change in the economic model, but also a change of ideas and lifestyles. Many of the ideas and lifestyles formed in the planned-economy era persistently remain, and the conflicts between different ideas constantly create important issues in social governance and the establishment of the rule of law in China.

As Lenin asserted, "thousands of millions of people's habits are the most horrifying powers to hinder...." ${ }^{5}$ While China has established the market economy, and people generally no longer worry about food and clothing in a prosperous and booming market, some selfish mindsets and behaviors, which have been formulated by the long-term lack of living resources in the planned economy, still persistently exist as social habits. It is not uncommon to see social conflicts and even criminal behaviors deriving from misconducts in public places, such as not waiting in line and arguing for seats on public transit. Civil disputes caused by social immorality

\footnotetext{
${ }^{5}$ See "Preface" in Collective Work of Lenin Vol. 39, Renmin News, online: <http://cpc.people.com.cn/GB/64184/180146/180269/12478396.html>.
} 
have become the majority of social problems in the new era. In addition, due to China's rapid economic growth after the establishment of a socialist market economy, the pace of social life has greatly accelerated. People are suffering more pressure due to increased living expenses and work, making anxiety and restless emotions prevalent in society. A considerable number of people are neither patient nor tolerant to even very small disparities or conflicts, which thus tend to intensify into larger social conflicts and become major social and legal issues.

\section{China is Shifting from Traditional Agricultural Society to Modern Industrial Society}

China is a traditional agricultural country with a small-scale peasant economy. Since the founding of the PRC in 1949, China has always been a country with an agricultural population as its main body. Before the 'reform and opening-up', China's urbanization grew very slowly, and the proportion of urban population was very small. In the $1980 \mathrm{~s}$, after thirty years since the founding of the PRC, the urban population rose from $11.18 \%$ to $19.39 \%,{ }^{6}$ and the agricultural population accounted for the overwhelming majority. Since the 'reform and opening-up', with the implementation of Rural Household Responsibility System and the rapid development of the national economy, the agricultural productivity has greatly improved, urban and rural barriers have gradually been broken, the surplus agricultural labor has migrated from rural areas to cities to work and live more freely, and China's urbanization level has greatly increased.

According to the report released by the National Bureau of Statistics on August 17, 2012, China's urbanization rate reached $51.27 \%$ in 2011, and the urban population reached 690.79 millions, surpassing the rural agricultural population for the first time. ${ }^{7}$ By 2014 , China's urbanization rate reached $54.77 \% .^{8}$ The rapid development of China's urbanization indicates that China has shifted from the traditional agricultural country to the modern industrialized country, which is consistent with the liberation of the agricultural labor due to the increase of agricultural labor productivity and the large-scale peasant migration to the cities. The labor transfer from rural to urban area is conducive to the adjustment of the agricultural structure in China, and to a

\footnotetext{
${ }^{6}$ See National Bureau, "Chinese Urbanization (1949-2013)" (2014), online: <https://wenku.baidu.com/view/3c4db18426fff705cc170ac1.html>.

${ }^{7}$ National Bureau, "Chinese Urbanization Reached 51.27\% in 2011" (2012), online: <http://finance.qq.com/a/20120817/004782.htm>.

${ }^{8}$ National Bureau, "Chinese Urbanization Reached 54.77\% in 2014" (2015), online:

<http://politics.people.com.cn/n/2015/0120/c70731-26417968.html>.
} 
large extent has lifted the persisting low-income farmers in the rural area from being constrained by the limited farming land.

One important feature of urbanization is the migration of rural surplus labor to cities, which is an inevitable trend of industrialization and modernization. However, a very important consequence is that many farmers who work in the city do not obtain the legal status of urban residents accordingly, which creates a unique disadvantaged community in China - the migrant workers. Since the founding of the PRC, China has established a dual social structure in urban and rural areas under the planned economic system. Under this system, the rural population could not flow freely into the cities. Since the 'reform and opening-up', the excess labor in rural areas has flowed into the cities to seek employment and entrepreneurial opportunities. To remove the barriers that prevented farmers from entering the city, the government has carried out several institutional reforms to abolish many unreasonable restrictions to the farmers' flow into the cities. ${ }^{9}$ This has facilitated them to work and live in the cities, to some extent. According to statistics, in 2014 the total number of Chinese migrant workers has reached 273.95 million. ${ }^{10}$ The large population of migrant workers has produced many new problems and challenges to China's governance model and for the establishment of the rule of law.

Under the existing urban and rural dual social structure, a person's household registration is not only the identity of an urban resident or a rural farmer, but also the qualification for a person to legally reside in a specific location, which directly or indirectly determines his or her employment, children's education, housing, healthcare, and many other social welfare provided by the central and local governments. As the household registration system in China is difficult to terminate or change in the near future, migrant workers are bound to run into a series of problems. Since they lack the household registration as urban residents, this triggers more unexpected and prominent social and legal problems including: low wages, seriously delayed payments, and long working hours; poor security conditions and lack of social security; increased occupational diseases, work injuries, and accidents; reduced training and employment opportunities; lack of children's education; poor living conditions; and so on. The difficulties in migrant workers' economic, political, and cultural rights and interests cannot be effectively

\footnotetext{
${ }^{9}$ Before the State Council issued "Measures for Assisting Vagrants and Beggars with No Means of Support in Cities" in August 1, 2003, migrant workers could be detained and repatriated if they had "no fixed place of residence, no means of livelihood and no permits to live in the city".

${ }^{10}$ Renmin News, "The Migrant Workers in China reached 274 million in 2014, increasing 1.9\%" (2015), online: <http://politics.people.com.cn/n/2015/0429/c1001-26923073.html>.
} 
resolved and have caused a lot of social conflicts and disputes. To solve these problems, or not, directly affects social fairness and justice, and social harmony and stability in China. ${ }^{11}$

The Chinese central and local governments doubtlessly have made great efforts in protecting the legal rights and interests of migrant workers in order to improve their working conditions and lives in the cities, and to some extent, have improved the protection of migrant workers' basic rights and their children's education in the city. However, as the migrant workers are poorly educated and thus incapable of resorting to legal instruments to protect their rights, the infringements of rights of migrant workers are still common and serious. For instance, employers refuse to sign a labor contract, reduce or delay wages, illegally extend working hours, fail to provide security facilities, refuse to pay social insurance, and so on. At the same time, with a low average income, migrant workers' living conditions in the city have generally been unsatisfactory. To make it worse, according to the existing policy, migrant workers in the city cannot enjoy the affordable housing rental and other housing benefits offered by the government to the low-income urban residents. Moreover, the children of migrant workers cannot enter the same public education system as the children of urban residents. For instance, in Shanghai, the children of migrant workers can apply for public education in only designated schools and under certain conditions (migrant workers must register for the Flexible Employment Program in the local community affairs reception centers for three consecutive years, and must be the holders of a 'Shanghai Temporary Residence Permit' for at least 3 years). However, this policy is only applicable to elementary and middle school education; the children of migrant workers can never enjoy the same pre-school, high school, and post-secondary education as those of Shanghai citizens. $^{12}$

In short, in the process of urbanization in China, migrant workers and their children entering the city from rural areas are not legally treated equally to urban dwellers. In fact, the migrant workers also have inferior social insurance, housing security, and child education than the other migrants from abroad or those with higher education. To make it worse, in practice, the social welfare policies for the migrant workers are poorly implemented. Migrant workers are in a disadvantaged and discriminative legal status, which is a major problem in China that needs to be

\footnotetext{
${ }^{11}$ State Council, "Opinions on Solving the Issues on Migrant Workers”, No.5, 2006.

${ }^{12}$ Hufubanfa No. 73, 2013, "Notice of Four Shanghai Municipal Departments on the Education in Shanghai of the Children of Immigrant Workers".
} 
promptly addressed by the political system, and the social governance needs to be strengthened by deepening reform.

The large number of migrant workers flowing into cities also had led to increased crimes committed by them. According to statistics, in recent years, the crimes committed by the migrant population, which is mainly comprised of migrant workers, has been increasing and have accounted for more than $70 \%$ of the total number of crimes in China. ${ }^{13}$ Furthermore, the crime rate of migrant workers has been rising alarmingly according to statistic on the current urban criminal cases. According to survey data, from 2006 to 2010, the migrant workers' crime rate increased by $21.7 \%$ from the previous five years. ${ }^{14}$ These high crime rates show that the social governance and the rule of law are not meeting the challenges derived from urbanization, which requires the Chinese government to seriously work out a solution.

According to statistics, migrant workers' crimes are mainly related to the infringement of property and personal rights, such as robbery, theft, intentional harm, traffic accident, rape, assistance with organized prostitution, etc. ${ }^{15}$ These crimes reflect a series of difficulties that migrant workers encounter in the city. First, they are suffering from the psychological shock due to the social gap between the rich and the poor and the pressure that comes with it. Without decent education and strong expertise, many migrant workers are in a disadvantaged position in the job market and can only find manual labour, which is often physically intensive yet with very low remuneration. Therefore, migrant workers can only afford rents in demolished shantytowns or dilapidated houses in remote city suburbs, purchase the cheapest food and poor quality clothing. Some new migrants find it hard to get employed and, thus, are in severe poverty and without any social welfare. However, the urban residents in the same city are living a more prosperous life. Some migrant workers, who are dissatisfied with the huge gap between migrant workers and urban residents, would take risks and commit crimes to 'get rich overnight'.

Second, some migrant workers commit crimes because they feel isolated in the city. Many migrant workers go to work in the city leaving their wives behind in rural areas to take care of the elderly, children, and farming, which tends to damage their marriages in the long run, and sometimes result in infidelity, separation, or even divorce. Suffering from this solitary

${ }^{13}$ Legal Daily, "New Features of the Migrant Population Crimes" (2014), online: $<$ http://www.legaldaily.com.cn/Police/content/2014-08/13/content_5717886.htm?node=53673>.

${ }^{14}$ China Broadcast, "Economic Difficulties Cause the Increase of Migrant Workers Crime Rate" (2012), online: <http://china.cnr.cn/ygxw/201207/t20120703_510094252.shtml>.

${ }^{15}$ Legal Daily, supra note 13. 
lifestyle, some migrant workers tend to commit crimes such as prostitution, rape, and other sexual crimes due to mental repression and disorder.

Third, some fatalities of migrant workers resulted from their ignorance and inexperience of the urban life. For example, many casualties of migrant workers happened due to traffic accidents. They are generally not familiar and lack access to information to get familiarized with the traffic rules in the city, and thus, they cross the road without looking at traffic signs or cycle in wrong lanes or direction, which causes great hazards to traffic safety and results in traffic accidents and even traffic fatalities. According to statistics, in recent years, China's rural population and urban migrant workers have become the main casualties of traffic accidents. ${ }^{16}$ For example, as early as 2008, the traffic accidents involving migrant workers accounted for $60 \%$ of all traffic accidents in Lanzhou. ${ }^{17}$ Some migrant workers even drove without driver's license, and fled after traffic accidents, which mostly resulted in being held criminally responsible. The government has the responsibility to inform migrant workers about the traffic laws and regulations, health and sanitary resources, and help them settle in the urban life as soon as possible.

Of course, some social and legal issues in the transition from traditional agricultural society to modern industrial society are not created by migrant workers only, but also derive from conflicts between the dramatically increasing urban population and the unchanged lifestyle of the urban residents. Industrialization and 'new technology' have greatly challenged the old social ideas and lifestyles and created many social issues and conflicts, such as euthanasia, homosexuality or same-sex marriage, which should be addressed by new legislation in China.

\section{Chinese Society is Moving from a Self-Enclosed Society to a Fully Open Society}

In the preliminary years of PRC, China developed diplomatic relations only with the Soviet Union, the Eastern European socialist countries, and some Scandinavian and Asian countries. In the 1960s, with the rise of the national liberation movement of the colonies, China established diplomatic relations with many newly established Asian and African countries. After Nixon's visit to China, and China resuming its seat in the United Nations in 1972, China has formally

\footnotetext{
${ }^{16}$ Lawtime, "Characters of Traffic Accidents", online: <http://china.cnr.cn>.

${ }^{17}$ Gansu Daily, "60\% of the Traffic Accident Casualties are Migrant Workers" (2009), online: $<$ http://lz.gansudaily.com.cn/system/2009/02/06/010981331.shtml>.
} 
established diplomatic relations with many Western countries and became an important member of the international political arena. By February 2015, China has established diplomatic relations with 172 countries. ${ }^{18}$

Before the 'reform and opening-up' policy, China had a self-supportive and selfsustained economy and an extremely closed society. It was difficult for the foreigners to visit China or for the Chinese to travel abroad. Even in Shanghai, the largest metropolitan city, foreigners were frequently crowded and watched by onlookers. In all, before the 'reform and opening-up', China was isolated from the rest of the world because of the Chinese government's foreign policy and its international context.

Since the late 1970s, when China carried out the national policy of 'reform and openingup', China has gradually opened its doors. In the early 1980s, China established four special economic zones in Shenzhen, Zhuhai, Xiamen, and Shantou. In 1984, 14 cities were designated as 'coastal cities' -Dalian, Qinhuangdao, Tianjin, Yantai, Qingdao, Lianyungang, Nantong, Shanghai, Ningbo, Wenzhou, Fuzhou, Guangzhou, Zhanjiang, and Beihai. In 1988, Hainan province was established and set up as a special economic zone. Soon, the State Council established 253 districts and counties as 'coastal economic development zones' in Yangtze River Delta, Pearl River Delta, Min Nan Xia Zhang Quan Delta, Liaodong Peninsula, Shandong Peninsula and other parts of the coastal areas. Since the 1990s and since the capital cities of the provinces along the national border carried out the 'open coastal city policy', China has established a nation-wide comprehensive opening-up structure from coastal areas to inland. ${ }^{19}$

On December 11, 2001, China officially joined the World Trade Organization (WTO), marking a new historical phase for China's opening up to the outside world. China has become the world's second largest economy by nominal GDP. In terms of foreign trade, China has replaced the United States as the world's largest trading nation. China's economy has been rapidly integrated into the process of globalization. At the same time, the cultural and personnel exchanges between China and foreign cultures has also been increasing and reaching an unprecedented level. Travel abroad has become very common. In 1998, the number of mainland China's outbound tourists was 8.43 million, and by 2014, mainland Chinese outbound tourists

\footnotetext{
18 "Timetable of PRC Establishing Foreign Relation with Other Counties" (2016), online: <http://www.gov.cn/guoqing/2012-04/20/content_2582734.htm>.

${ }^{19}$ Zheng Yanzhu, The Foreign Investment Law in the Chinese Coastal Cities, (China: Shanghai Academy of Social Sciences Press, 1995).
} 
exceeded 100 million for the first time, increasing 10.8 times. ${ }^{20}$ At the same time, the number of foreign tourists visiting China has also been increasing year by year. According to statistics, in 2013, China had nearly 130 million inbound tourists throughout the year. ${ }^{21}$ China has changed from the original closed-door country to full openness at the present. China is facing many new challenges and new social and legal problems as its economy is more integrated into the world's economy, and the country is more open to the world.

a) The International Economic and Trade Rules

Since China entered the WTO, the Chinese foreign trade has developed rapidly, but many Chinese enterprises and government departments are still not familiar with the relevant international economic laws. In order to compete for foreign markets, some domestic enterprises often blindly lower prices, resulting in vicious competition. Additionally, to encourage enterprises to increase exports, some government departments assist with loans and funding, provide tax refunds, and other assistances. These supports not only lower the profits of Chinese export enterprises (some export companies earn no profits at all, and make income only with export tax rebate), but also make them subject to legal suits of anti-dumping and countervailing measures from the importing country. According to statistics, from December 2001 to December 2014, China has been sued by other countries in 32 WTO cases, mainly regarding government subsidies, anti-dumping, and countervailing measures. ${ }^{22}$

b) Foreign Affairs Management Capacity of Local Government Departments Since the 'reform and opening-up', many foreign companies and institutions have invested and set up factories in China, many foreigners now work and live in China, and several foreign governments have set up consulates in Chinese cities. The Chinese local governments are dealing with increasing foreign affair issues, which require professional staff with the knowledge and expertise of international laws and foreign diplomacy. For example, Shanghai has 75 foreign general consulates (including three honorary consulates and one honorary consul), ${ }^{23}$ and has

\footnotetext{
${ }^{20}$ Renmin News, "Chinese mainland outbound tourists reached 100 million in 2014" (2014), online: <http://travel.people.com.cn/n/2014/1203/c41570-26141388.html>.

21 “Annual Report on China's inbound tourism in 2014”, online: <http://www.cssn.cn>.

22 "China involved in 32 WTO Suits for anti-dumping and countervailing" (2015), online:

$<$ http://www.legaldaily.com.cn/index/content/2015-02/01/content_5953310.htm?node=20908>.

23 "List of Foreign Consuls in China", online: 〈http://www.fmprc.gov.cn〉.
} 
become the city accommodating the second largest number of foreign diplomats after Beijing. Some diplomatic personnel working in the consulates have disobeyed the traffic rules by driving a consulate licensed vehicle, and traffic police did not stop them believing they enjoy diplomatic privileges. In fact, this reflects that some of the traffic police lack the necessary knowledge of international law, and thus hesitate to claim jurisdiction and sovereignty. In another example, a few years ago, a foreign cruise landed in Shanghai port, and a Chinese tourist refused to get off because of dissatisfaction with the travel agency. The ship sought help from the local police, however the local police were afraid to violate foreign affairs policy and refused to help due to lack of knowledge of international law. If the police were aware of the Vienna Convention on Consular Relations and the bilateral consular treaties between China and the country of origin of the cruise, the police would have exercised their jurisdiction in accordance with the law. These examples show that Shanghai's government departments lack sufficient capacity to deal with foreign affair issues, even though Shanghai is the largest international city in China.

Openness to the world has required the Chinese administrative departments to go beyond borrowing foreign laws in the legislation and get familiar with the rules and practices of international laws. The criteria of an international city are not only the 'hardware', its construction of the city, but also the 'software', the management ability of the city.

\section{Chinese Society is Shifting from the Rule of Man to the Rule of Law}

The Fourth Plenary Session of the Eighteenth Central Committee of the CPC established the overall goal and road map for the complete construction of China into a socialist country under the rule of law.

In theory, as the CPC has transferred from a revolutionary party to the ruling party, it should rely more on the use of law than the previous use of policy and govern the country according to rule of law. However, for a long period of time, the CPC did not completely switch its governance strategy to the rule of law for multiple reasons. Firstly, China has two thousand years of feudal monarchy, has not gone through a thorough bourgeois revolution and thus lacks the bourgeois rule of law. Rule of man has been embraced deeply by the rulers and society and could not be easily changed into the rule of law. The CPC exercised the ruling power by fighting for the old law and order, relying on flexible policies rather than on laws to solve the problems. 
When the PRC was established, the CPC continued launching large-scale mass campaigns to carry out production and construction, and relied on policy rather than the law to govern the country. Although the Party and the government tried to establish the rule of law shortly after the founding of the PRC, this effort was disrupted by the 'Cultural Revolution.' The rule of man remained as the only option for the Chinese.

After more than 30 years of the 'reform and opening-up', the Party's ruling idea has undergone major changes, provocatively advocating governing the country according to the law and building the socialist rule of law. The Chinese legal system has made unprecedented achievements. On March 10, 2011, Chairman Wu Bangguo announced that the socialist legal system with Chinese characteristics was established. By the end of August 2011, the National People's Congress had made more than 240 laws, 706 administrative regulations promulgated by the State Council, and 8600 local rules and regulations, which cover all aspects of social relations in China. ${ }^{24}$ However, it is a very long process from the establishment of a legal system to the finalization of a rule of law society. As the rule of man idea had existed in China for a very long time, and while it is easier to demolish the rule of man in the legal system, the rule of law is far from being easily established in people's minds. Moreover, well-made legislation does not guarantee well implementation and compliance with the law. Practice has proved that only the effective implementation and compliance with the law can really establish the authority of the law.

People are very dissatisfied with the current situation of law and order in China, criticizing that the government "makes law comprehensively, breaks law universally, and enforces law selectively." The government officers' "powers, their leadership and leaders' speeches are all superior to law." The ordinary people "trust appellation rather than law for dispute resolutions." 25 This situation must not continue to exist, as it does great damage to law and social order. However, we are pleased to see that with the deepening of the construction of the rule of law society, this phenomenon is now being effectively corrected, and will be eliminated in the process of governing the country by the rule of law.

\footnotetext{
24 The Socialist Legal System with Chinese Characteristic (Whitepaper), online: Xinhua news <http://www.gov.cn/jrzg/2011-10/27/content_1979498.htm>.

25 Yawei Dong, "Solving Social Disorder by Rule of Law", online: http://opinion.china.com.cn.
} 


\section{Conclusion}

It has been proven with the experience of the 'reform and opening-up' that only the road of the socialist rule of law can guarantee China's long-term stability. In China, which has a long tradition of the rule of man, efforts must be made by several generations in order to establish a socialist society with the rule of law. In all, to achieve this goal, we must be honest and stick to China's social and political context. We must explore the roots of China's various social and legal problems that derive from the transitional creation of Chinese society, find ways to solve these problems, and finally establish the socialist rule of law in China.

\section{References}

1. The Socialist Legal System with Chinese Characteristic (Whitepaper) (2011), online: Information Office of the State Council, The People's Republic of China <http://www.gov.cn/jrzg/2011-10/27/content_1979498.htm>.

2. The Decision of the Central Committee of CPC on the Major Issues of Comprehensively Deepening Reform, Renmin Press, 2013.

3. The Decision of the Central Committee of CPC on the Major Issues of Comprehensively Furthering Governing the Country According to Law, Renmin Press, 2014. 